\title{
SPEECH ACTS ON COMPANY'S PRESENTATION IN GERMAN FOR BUSINESS AND ECONOMICS
}

\author{
Mery Dahlia Hutabarat \\ Universitas Pendidikan Indonesia \\ mery59@yahoo.de
}

Article received: 5 August 2014

Final proof received: 28 June 2015

\begin{abstract}
The research is aimed to analyze text presentations of companies profiles and their products information. The topic is included under Wirtschaftsdeutsch, or "German for Business and Economics." The analysis of sentences and the elements contained in the text presentation of 14 companies draws upon the theories of speech act analysis by various experts in linguistics, such as Austin, Searle, and Engel. The functions of sentence elements are studied based on the theory of dependency grammar put forward by Engel. There are 85 sentences as the data. The speech act dominating the text presentation of the companies' profiles under study is notification in a narrow sense, that is, exercitation, and it refers to the interlocutor as hearer. The dominating elements in the sentences of the companies' profiles under research are subjects and Akkusativergänzungen (indirect object). Meanwhile, product presentations are dominated by nominal phrases.
\end{abstract}

Keywords: Wirtschaftsdeutsch, text presentation, speech acts, dependency grammar.

Speaking is the most difficult competence that should be mastered by foreign language learners because of the four language skills it is regarded as the most difficult one. Many theories mention that speaking competence is highly supported by other language competences, such as comprehension competence in listening and reading as well as good knowledge, both in vocabulary and grammar. The teaching and learning of German skills for the first to the fourth semester students usually cover linguistic aspects with general themes. The higher the level of German knowledge that a learner takes, the higher the level of material difficulty the learner should learn. This phenomenon can be observed from the content of German teaching and learning in the subject of "German for Specific Purposes" for economic enterprises given in the sixth and seventh semesters. This fact also refers to the difficulty levels of German for B2 level based on CEFR or Common European Framework of Reference, which is the standard reference for German language competence in Europe.

Graduates of German Education Department, in particular, should be able to master one of the speaking competences in non-education field, presenting the profiles of their future companies, among others. There is also an opportunity that one day graduates of German Education Department should present their company's products to the German speaking guests or in one of the exhibitions in Germany. Hence, it is highly required to research things pertaining to presentation. The utterances to be used in a presentation include formal utterances that can be memorized by a German learner. Among the utterance patterns are (1) to start a presentation, or called "einführung", or "einleitung" utterance pattern; (2) to deliver presentation content and utterance pattern; (3) to close and provide opportunities for inquiry to the guests.
It is highly possible that there will be similarities in the utterance pattern of one company to another. Differences in utterance pattern are possibly found in the specialization of each company. Thus, the issues under study are formulated as follows: 1) How are utterances formulated for the presentation of company's profile? 2) What verbs are frequently used in the utterances of company's presentation? 3) What are the syntactic functions of the elements correlating to the verbs? and 4) What types of speech acts are used in business communication, ultimately in presenting company's profile and its products?

Meanwhile, the aims of the research are formulated in the following ways: 1) To describe utterances in the presentation of company's profile, 2) To analyze German verbs frequently used in the utterances of company's profile, 3) To analyze the syntactic function of the sentence elements correlating to verbs, and 4) To analyze the types of speech acts found in business communication, ultimately in the presentation of company's profile and its products.

The nature of speech acts "sprachhandlung" There are some Indonesian equivalents for the term "speech acts". According to Subyakto (1990), the equivalent word of speech acts is "tindak bahasa". This is in accordance with the translation of speech acts in German, namely Sprachhandlung. Hutabarat (1991) uses the term "tindak ujaran" because the language or phrasal element in her research is a short utterance, namely the statement for thanking and apologizing. However, in this research, both the terms of tindak bahasa and tindak ujaran are not used; instead, the equivalent phrase of "tindak tutur" is employed because the linguistic element under research is the one used for oral 
communication. In addition, speech acts can be in the forms of a word, a phrase, or a long sentence. Thus, the linguistic elements that will be researched can be in the forms of phrases, sentences, or paragraphs.

Brandt et al. (2006) interpreted speech acts theory developed by Austin and Searle under the influence of Ordinary Language Philosophy, attempting to test the hypothesis in their book of Speech Acts. The theory states,

Speaking in a language is an attitude influenced by rules. A speech act is the production of a language sign called "sentence" with certain requirements. Speech act is the smallest fundamental unit of communicating language. Speech acts depend on the meaningful attitude or intention and the aim of the speaker while uttering them. In uttering, special intentions of language facts for speech acts are revealed. (p. 291)

Furthermore, as described by Oishi (2006, p. 5), Searle who is a major proponent of the speech act theory adopts Austin's ideas and elaborates some of them (Searle, 1969 in Oishi, 2006), until finally develops the theory in his own fashion: The essence of it being that to perform an illocutionary act is to express an illocutionary intention (Searle, 1979, in Oishi, 2006). Searle's notion of the speech act theory is developed along this line, and Searle (1983, as cited in Oishi, 2006) and Searle and Vanderveken (1985, in Oishi, 2006) attempted to explain illocutionary force in a formal model which is compatible with the formal analysis of propositional contents (p. 5).

Austin's argument as interpreted by Meibauer (2007: 230) holds that "now utterances are understood as acts". Another definition on Sprechakt is put forward by Lewandowski (1990, p. 1080), saying "Sprechakt (speech act, acte de parole, recevojakt/aktreči. Segment der rede, situativ-intentionale und bedeutungs volle artikulatorisch-akustischeeinheit, die sprecher und hörer in einerbestimmten situation durch für beideg leichebe deutung enverbindet", which means "Speech acts are conversational elements, an articulatory and acoustic entity full of meanings and intentions in line with a certain situation, connecting the speaker to the hearer in a situation through meanings understood by both of the people involved in the conversation."

In this research, speech act is understood as a sentence or a series of both sentences and phrases that have meanings or intentions in order for the hearers to not only understand the content of the utterance, but the interlocutors are also expected to act, making business transaction or ordering or purchasing goods or items explained in German in the immediate context.

\section{Speech acts classification}

Austin (1962, p. 108) broadly classified speech acts into three types; namely a) locutionary acts, b) illocutionary acts, and c) perlocutionary acts. This classification by Austin was also used by Gross (1988, pp. 147-148) and Lewandowski (1990). Furthermore, Austin explained the three types of speech acts as follows:

a) Locutionary act, which is roughly equivalent to uttering a certain sentence with a certain sense and reference, which again is roughly equivalent to 'meaning' in the traditioal sense.

b) Illocutionary acts, such as informing, ordering, warning, undertaking, $\&$, i.e. utterence which have a certain (conventional) force.

c) Perlocutionary acts, that is, saying something, such as convincing, persuading, deterring, and even, say, suprising or misleading.

Bazerman (2004) interpreted these three types of speech of acts as follows:

Illocutionary act is literally what is said. So in saying that "it is a bit chilly in this room," I am reporting on a state of affairs and making a certain proposition about the temperature in the room. (...). By speaking indirectly I intended my words to have a specific illocutionary force, which I assume others would recognize given the immediate circumstances and the manner of delivery of the sentence. The act I intend my hearer to recognize is the illocutionary act. (...). How people take up the acts and determine the consequences of that act for future interaction is called perlocutionary effect. To make the issue even more complicated, listeners may not be happy or cooperative with what they understand me to be doing, and in their further utterances and acts they may not go along with it ( $\mathrm{p}$. 14).

In addition, the twelfth lecture of Austin (1962: p. 150) contains the classification of speech acts namely: 1) verdictives, 2) exercitives, 3) commissives, 4) behabitives, and 5) expositives. The examples of each of these types of speech acts are as follows (Austin, 1962, p. 152 ff):

1) The examples of verdictives are: (a) calculate, (b) assess, (c) estimate etc; 2) exerzitives; (a) appoint, (b) order, (c) direct, (d) grant, (e) claim, (f) warn, etc; 3) commisives: (a)promise, (b) undertake, (c) declare my intention, (d) purpose, (e) guarantee, (f) agree, etc.; 4) behabitives: (a) apologize, (b) compliment, (c) congratulate, (d) condole, (e) curse, (f) challenge; and 5) expositives: explains what position taken by one's utterance in a conversation or discussion; for example: (a) affirm; (b) state, (c) remark, (d) inform, (e) accept, (f) agree, etc.

2) Examples of the kinds of sentences in German put forward by Karagjosova (2007: p. 6) referring to speech acts, namely ratschlag "suggestion", for example, (a) Kaufbei Maier! "Shop at Maier store"; verwünschung "curse", for example: (b) Gehzumteufel! "Go to hell"; wunsch "prayers and expectation": (c) Bleibgesund! "Stay healthy"; beleidigung "insult", for example: (d) Halt's maul! "Shut your mouth"; frage "question": (e) Sag mir doch mal, wie fühlst du dich? "Tell me, how do you feel?"; the example for bitte "request": (f) Mach bitte die türzu! "Please close the door"; and finally, the example for erlaubnis "permission"; (g) Gehnur! "Go!".

Meanwhile, Engel (1988, p. 36) classified speech 
acts based on the speaker's perspectives. Therefore, Engel divided speech acts into two major groups, which are 1) partnerbezogenesprechakte "speech act referring to the interlocutor" and 2) sprecherbezogenesprechakte "speech act referring to the speaker him/herself, without an interlocutor."

1) Partnerbezogenesprechakte "speech act related/referring to the interlocutor", is divided into:

a) Mitteilungsakte "notification": Mitteilung im engeren sinne "notification in a narrow sense", zustimmung "to agree", ablehnung "to reject" (zurückweisung "rejection", widerspruch "denial", Korrektur "correction"), intensivierung "intensification", generalisierung "generalizatio", kommentierung "comment", einschränkung "restriction", paraphrase "to change utterance formulation", kontaktsignal (hörer) "to give signs that the hearer listens to the speech".

b) Ausgleichsakte "stabilizing speech act": Dank "thanking", entschuldigung "apologetic utterance", aufhebung "reply utterance for expressions of thanking or apology", billigung "utterance for agreement" gratulation "congratulatory expression", kondolation "condolence".

c) Personenfestlegendesprechakte: "Speech acts referring to the persona" $d e n$ sprecherfestlegendeakte "speech act referring to the speaker": versprechen "speech act of promising"

c1) Den partnerfestlegendeakte "utterance referring to the interlocutor": aufforderung "command", autorisierung "validation", ratschlag "suggestion", vorwurf "accusation", beschimpfen "curse", warnung "warning", frage "question" (entscheidungsfrage "close-ended question", sachfrage "open-ended question", alternativfrage "question containing alternatives", gegenfrage "repetitive question", rückfrage "query"), kontaktsignal (sprecher) "signs of contact from speaker".

c2) Sprecher- und partnerfestlegendeakte "speech acts referring to the speaker and interlocutor": angebot "offering", drohung "threat", kontaktumgrenzung "contact restriction" (gruß "saluting/greeting”, anrede "speech act of name mentioning", vorstellung "introductory utterance", adresse "address", absender "sender")

c3) Beliebigepersonenfestlegendeakte "speech acts referring to certain persona": (wunsch "wish", vorschlag "suggestion", ankündigung "announcement”)

2) Sprecherbezogenesprechakte "speech acts related to the speaker him/herself" "(self-talking)": schimpfen "cursing oneself", überraschung "being surprised and talking to oneself", resignation "speech acts stating the sign of resigning".
On the concept of speech acts of mitteilungenimengerensinne or "notification in a narrow sense”, Engel (1988, p. 37) explained:

Unter mitteilungen im engeren Sinne sind die primär informativen sprechakte zu verstehen, die initiativ (d.h. nicht reaktiv) sind, keine intensivierende, generalisierende, kommentierende, einschränkende oder paraphrasierende komponente aufweisen und auch nicht als bloßes kontaktsignal fungieren.

It means: "Notification in a narrow sense is understood as a primary informative speech act with initiative function and does not show intensification, generalization, comment, restriction, changes of the previous utterances, and also does not function merely as contact signal." Engel further suggested that "Mitteilungenimengeren Sinnesind initiative Sprechakte: Siesetzen Voräu ßerungenvoraus", meaning that "notification in a narrow sense is an initiative of speech act that does not require previous utterances of the interlocutor" (p. 38).

On the other hand, utterances performing such functions are described as performatives. Allan (1986) as cited by Al-Shaer (2013 p. 225) pointed out that performative utterances, or performatives, can be classified as direct or indirect speech acts. A direct speech act has illocutionary force made explicit by means of a verb, such as promise, warn, apologize, congratulate, among others; meanwhile, the illocutionary force of an indirect performative utterance is made implicitly, i.e. without a performative verb.

To analyze the utterances found in the presentation of company's profile and its products, Engel's classification is used. The speech act classification of partnerbezogene Sprechakte "speech acts referring to the interlocutor", particularly Mitteilungenimengeren Sinne "notification in a narrow sense", is deemed highly appropriate for the presentation of company's profile because interlocutors spend more time listening and do not produce utterances before the presentation is begun.

\section{The concept of German for business and economics "Wirtschaftsdeutsch"}

The presentation of company's profile and its products' information is included in the teaching materials of German for business and economics, which is termed Wirtschaftsdeutsch in German. When German learners are given the material of Wirtschaftsdeutsch, it does not necessarily mean that they study economics and business; rather, they study German used in the conversation of economics and business. Wirtschaftsdeutsch is one of the Fachsprache, or what Hutabarat (2009, p. 60) termed 'professional language variety' [RBP or Ragam Bahasa Profesi in Indonesian]. It is the entity of all language tools used in a restricted communication in one field of expertise to ensure understanding between experts working in that field. Hutabarat (2009,) later translated Winfried's opinion pertaining to Fachsprache as follow: 
Professional language variety refers to languages used in the fields of communication that are technically or scientifically-oriented, with information generally referring to a profession and tend to be made standard, given values, and formalized as utterances, with prominent characteristics of having their own vocabulary pertaining to certain professions; for instance, technical language, administration, language of the diplomas, sport language, and the like. (p. 60)

\section{Speaking skill in the presentation of company's profile and its products' information}

Speaking is the most difficult language skill compared to the three other skills, which are reading, listening, and writing. As cited in Lewandowski (1990, p. 1087), speaking has several definitions. For this research, the definition used is "Sprechen ist ein komplizierter, physiologischer vorgang der artikulation, bei dem das neurale steuerungssystem des sprechers die jeweils zu produzierenden laute antizipiert und die lautproduktion durch hören kontrolliert und korrigiert". This means, "Speaking is a complex physiological articulatory process. During speaking, the speaker's neural control system anticipates each sound that should be produced and controls as well as corrects sound production during listening".

In this regard, Hutabarat (2013, p. 89), quoted Lado's opinion (1971, p. 278) as follow:

„Wir definieren die mündliche sprachproduktion oder sprechfertigkeit als die fähigkeit, in grundlegend normalenkommunikationssituationen die sygnalsysteme deraussprache, der betonung, der intonation, der grammatischen strukturen und des vokabulars einer fremdsprache zu benutzen, und zwar in einer für sprecher dieser sprache normalen darbietungsgeschwindigkeit. "

This translates as, "Oral language production or speaking skill is defined as the ability to use pronunciation signal system, tone and intonation, grammatical structure and vocabulary of a foreign language in a communication situation that is basically normal, and in a normal speed of speech for the native speaker of the language".

From the above definitions, it can be inferred that when producing oral language, German learners should not only use the pronunciation ability, but also grammatical structure and appropriate vocabulary, and speak fluently in accordance with their German language proficiency level based on CEFR. If learners learn to speak, it means that they learn to interact with others because they want to achieve something. In other words, they want to ask for something or give information to their interlocutors.

\section{Dependency grammar}

To analyze the functions of the elements contained in the sentences as data of this research, the researcher used dependency grammar theory. This theory was developed by Lucienne Tesniere, a French linguist (1959). Tesniére's theory of "Elements de syntaxestructurale" is used by German linguistic experts as a didactic basis for analyzing the function of syntactic elements of the sentence. This theory was developed in Germany, known as "Dependenzgrammatik" (dependency grammar). On this theory, Tarvainen (1981: p. 12) said:

Aus der Sicht der Dependenzgrammatik stellt der Satz eine hierarchie Struktur dar, die aus verschiedenen Stufen besteht. Dabei wird auf jeder Stufe ein Element als dominierend, als Regens betrachtet, von dem die übrigen als Dependentien abhängig sind.

It means "According to dependency grammar theory outlook, the sentence is a tiered structure consisting of different levels. At each level, there is a dominant element that was considered as a determinant (governor). Based on this theory, the analysis of syntactic function should refer to the verb". Verbs are indeed very dominant in determining the complementary elements, especially in terms of cases carried by a noun or pronoun.

In line with the above definition, Debusmann \& Kuhlmann (2006) explained:

With the concept of a dependency structure at hand, we can express linguistic universals in terms of structural constraints on graphs. The most widely used such constraint is to require the dependency structure to form a tree. This requirement models the stipulations that no word should depend on itself, not even transitively, that each word should have at most one governor, and that a dependency analysis should cover all the words in the sentence. (p. 3)

\section{METHOD}

The research is qualitative, describing and analyzing sentences found in the 14 text presentations of companies' profiles and products information presentation of two companies. Data in the form of speech acts were obtained from various books on Wirtschaftsdeutsch, observations and interviews with businessmen speaking German running their business in Indonesia, and also with Indonesian employees who could speak German well. Data were also gained from interviews in the cities, where there were German companies running their business in Indonesia and Indonesian companies in a partnership with German companies.

Population involved include all businessmen who are native speakers of German and all Indonesian employees working at German companies or in partnership with German companies who can speak German. Samples were derived from the list of German businessmen contacted at some German companies who were willing to be interviewed. Random sampling technique could not be applied because it was highly dependent upon the willingness and interest as well as time availability of the businessmen. Indonesian employees working at German companies were also limited to those who graduated from German Education Department who provided information on where they worked. The research was conducted in the period of eight months, starting from proposal drafting in the mid of May 2013 to the writing of research result report ended in November 2013.

The research took place in big cities, where the 
business was run by German companies or Indonesian companies in partnership with German companies. It was begun by collecting data in the forms of presentation samples contained in imported Wirtschaftsdeutsch and matching them with interview results, followed by analysis of the functions of the sentences' elements. The data were then analyzed based on the types of speech acts referring to the interlocutors based on Engel's theory of speech acts.

\section{RESULTS}

\section{A. Description of company's text presentation}

Description of text presentation of company's profile The data of the present study were derived from the presentation of 14 German companies engaged in various business fields, like pharmacy, car spare part supplier, computer, telecommunication, metal, power plant, among others, etc. The names of the companies listed in the text presentation of the companies' profiles are Lichtwer Pharma, MAGNA, Bosch Telekom, HENKEL, Victorinox, Reemtsma, Junker der Robert Bosch GmbH, and "Otto Versand".

Below are examples of utterance formulation for the presentation of companies' profile along with their translation. (Source: Buhlmann et al. 2003, p. 146)

Description of Utterance Formulation for the Presentation of Lichtwer Pharma Company's Profile

Lichtwer Pharma entwickelt, produziert und vertreibt weltweit pflanzliche Arzneimittel mit gesicherter therapeutischer Wirksamkeit. Wir sind ein überdurchschnittlich erfolgreiches und konzernunabhängiges Unternehmen mit eigener Forschung, das national und international an Bedeutung gewinnt. Unsere Marken (u.a. Kwai, Jarsin, Kira, Sedonium) machen Märkte. follow:

The above presentation can be understood as "Lichtwer Pharma develops, produces, and markets herbal medicines with proven therapeutic efficacy. We are an exceptionally independent and successful company with its own research. Our company is gaining national and international importance. Our product brands dominating the market are, among others, Kwai, Jarsin, Kira, Sedonium".

Utterance Formulation of HENKEL company's product presentation

a) Wasch-/und Reinigungsmittel'Powder and liquid cleaner"

Glanz und Sauberkeit fürs Haus: Henkel bietet eine große Auswahlan Universal-und Spezialwaschmitteln sowie Reinigungsmitteln.

"Shine and cleanliness for your house. Henkel presents a variety of universal and special powder and liquid cleaners."

Das Produktportfolio wurde durch die Akquisition der Dial Corporation im März 2004 noch erweitert.

"The product portfolio further was enhanced by the acquisition of The Dial Corporation in March 2004." ZuunserenführendenMarkengehören'Our wellknown powder and liquid cleaner productbrand':

Persil: Universalwaschmittel Nummereins "Number one universal cleaner."

Vernel: Weiche Wäsche, zarter Duft "Soft cloth", "gentle fragrance"

Dixan: Champion gegenflecken "Champion in fighting dirt/stains"

Somat: Geschirr und besteck glänzend sauber "Glassware: clean and shiny"

Prill: höchstefettlösekraft "Strongly removes thick fat"

Bref: gegen fest sitzende verschmutzungen "Against sticky dirt

b) Kosmetik/Körperpflege "Cosmetic and Body Care" Leichter, besser - und vor allem schöner sollen Henkels kosmetik-und körperpflegemarken das leben der verbraucher machen: mit unserer vielfalt an produkten für haarkosmetik, körper-, haut- und mundpflege, parfüms und speziellen produkten für das frisörgeschäft. " "Easier, better ... and especially to make the consumer's life more beautiful, that is what Henkel's cosmetic and body care brand is made for: with our diversity of products for hair care, body-, skin- and mouth care, parfume and special products for the hair salon business."

Fa: Die wilde frische in der körperpflege "Amazing freshness in body treatment"

Schauma: Kraft bis in die spitzen "Power to the max"

Gliss Kur: Für haare wie seide "For silky hair" Taft: Perfekterhalt und optimalerschutzfürshaar "Perfect toughness and optimal protection for hair."

Colorationen: Fürunwiderstehlichefarben "For long-lasting color"

Deadermine: Pflegeliniefürsgesicht und körper "The best facial and body treatment"

Theramed: Die cleverezahnpflege "Clever dental treatment"

Osis: Fürultimativestylings "For ultimate style"

From the above examples, it can be clearly seen that the presentations of company products are not only in sentences, but also in nominal phrases.

\section{B. Description and analysis of the function of German linguistic elements in companies'} profiles and products' information presentation

Analysis of the function of sentence elements in the text presentation of companies' profiles

From the 14 text presentations of company's profile, a number of 85 sentences are found to have subjects, predicates and complements, or what is called Ergänzungen in German, and also adverbs or Angaben. There are 59 verbs in the 85 sentences that are present as many as 114 times. 41 verbs are classified into regular verbs (regelmäßige Verben) and 18 verbs are categorized into irregular verbs (unregelmäßige Verben), which are beginnen "to begin" schaffen "to create/to succeed", 
übernehmen "to take over", etc. The most productive verb is sein or "to be" which comes up 27 times, "sind" 14 times and ist 12 times as well as in the past form of Präteritum war once. There are 54 verbs functioning as main verbs or Hauptverb. Only one verb functions as auxiliary in perfect tense, which is haben, correlating to the main verb of entwickeln in the form of Partizip Perfekt; it changes into entwickelt "to develop". The verb haben serves as the main verb as well in other data. The other four auxiliary verbs are modals or Modalverben, namely wollen "will", correlating to the main verb of ausruhen "to rest" and the main verb of einstellen "to place".

Examples for main verbs that are quite productive are, among others, entwickelt "to develop" (4 times), produziert "to produce" (3 times), suchen "to search" (3 times), and beschäftigt "to employ" (2 times). Among the 54 main verbs, seven prepositional verbs are found, including (a) gehörtzu "to include" (b) gewinntan "to gain", (c) legen auf (Wert) "to appreciate", (d) sichorientieren an "to be oriented to", (e) stehtfür "to be impartial with", (f) sorgenfür "to pay attention to", (g) zähltzu "which is included in".

In addition to the above verb types, there are also reflective verbs, namely (sich) ausruhen "to rest", sichbefinden "to be in a certain place", (sich) orientierenan "to be oriented to". There are four verbs with special meanings in business, which are (a) produziert "to produce", (b) untermauern "to corroborate", (c) vertreibt "to market", and (d) wirtschaften "to manage".

The most dominant subject in the text presentation of the company's profile is personal pronoun of wir or 'we'. Its frequency is 32 . The personal pronoun of sie 'she/the feminine pronoun' for the third singular person as the pronoun of Verfassung 'state' is only present once. Company's name and nominal phrase correlating to company's name serving as subjects are found 17 times. Subjects in the forms of other nominal phrases and also personal pronouns and definitive articles appear 21 times.

From the 85 data, 42 elements functioning as accusative complement 'Akkusativergänzung', four verbs with valency of dative complements 'Dativergänzung' in four data are found. Other complements found in the data are prepositional complement 'Präpositivergänzung' as many as seven, modificative complement 'Modifikativergänzung' as many as three, predicative complement for four data, and situative complement 'Situativergänzung' as many as two data. 20 data with nominal complement 'Nominalergänzung' are also found.

\section{Analysis of Speech Act Types Found in the Presentation of Company's Profile}

It was found that the most dominating speech act is Mitteilungenimengeren Sinne 'notification in a narrow sense'. This type of speech act does not require Voräußerungen "initial speech act". In other words, the speaker does not have to wait for an initial speech act that $\mathrm{s} /$ he listens from his/her interlocutors; in this case, the company's guests. Sequential information is given by the speaker. This is very obvious in 32 sentences with the subject of wir or "we". The content information shows the company's success being presented and represented by the presenter by mentioning "we". Below are three of such sentences.

(1) Mit einem Umsatz von 1,5 Milliarden Euro sind wir heute bereitsdie Nummer Fünf aller unabhängigen Softwareanbieter weltweit-und wir wachsen ständig.

"With a turnover of as much as 1.5 billion Euros, we are the fifth highest of all independent software companies running in the whole world-and we continue to develop."

(2) Wir sind einerfolgreiches und stark expandierendes Unternehmen der Metall- und Kunststoff verarbeitenden Industrie und seit vielen Jahren erfolgreicher Partner der in- und ausländischen Automobilfirmen.

"We are a successful and rapidly expanding company in the metal and plastic processing industry and for many years a successful partner of domestic and foreign automobile companies."

(3) Mit unseren Marken Vichy, Phas und La RochePosay sind wir seit Jahren dasführende Unternehmen auf dem Gebiet apothekenexklusiver Kosmetik. "With our brands Vichy, La RochePosay, and Phas we have for years been the leading company in the field of pharmacyexclusive cosmetics."

The sentence elements underlined in the above examples are some of the notifications of a company's success being presented. The notification is of course not inquired by the hearer or interlocutor. However, this notification of success will convince the hearer as a prospective buyer.

The same is true for sentences with the subject of a company's name (17 sentences) and other nominal phrases ( 12 sentences) categorized into Mitteilungenimengeren Sinne "notification in a narrow sense". All of which is information on the success and competence of the company being presented. Three examples and their translations can be seen in the following sentences:

(1) Auf dem Wachstumsmarkt der

Kommunikationstechnik zählt Bosch Telekom

zuden namhaften europäischen Anbietern.

"In the growing market of communication engineering, Bosch Telekom is one of the renowned European suppliers. “

(2) Die Reemtsma Zigarettengesellschaften sind das am schnellsten wachsende Zigarettenunternehmen der Welt.

"Reemtsmacigarette company is the world's fastest growing cigarette company."

(3) Der Geschäftsbereich Junkers der Robert Bosch GmbH ist ein führendes europäisches 
Unternehmen der Thermotechnik.

"The Junkers division of Robert Bosch GmbH is a leading European company in thermal technology."

The presence of other types of speech acts can be seen in the beginning and end of presentation. This can be seen from the utterance formulation of the presentation of OTTO Company's profile as follows:

Sprecher'speaker':

(1) Guten Morgen/Tag, meine Damen und Herren "Good morning, ladies and gentlemen."

(2) Herzlich willkommen in unserer Zentrale hier in Hamburg.

"Welcome to our head quarters here in Hamburg."

(3) Zuerst möchte ich Ihnen kurz etwas über den OttoKonzern erzählen.

"First, I would like to briefly tell you about the Otto Group."

(4) Otto ist in erster Linie ein Versandhaus, das Waren per Katalog und Online-Bestellung verkauft und den Kunden direkt ins Haus schickt.

"Otto is primarily a mail order company that sells products via catalog and online ordering that are sent directly to the costumer's house."

(5) Insgesamt gibt es mehr als 600 Kataloge pro Saison. Den deutschen Hauptkatalog mit dem Motto "Ist es trend, hat es Otto "kennen Sie sicher.

"There are more than 600 catalogs per season. The main German catalog with the slogan 'It is trendy, it has Otto," you surely know."

(6) Er bietet auf 1300 Seiten über 25000 Produkte an, vor allem Bekleidung und Schuhe.

"He offers in 1300 pages over 25000 products, especially clothing and shoes."

(7) Darüber hinaus gibt es hier mehr als 20 Spezialkataloge, zum Beispiel ,Multimedia“, „,Baumarkt", „, Klitzeklein“ „, Gartencenter", oder „,p.s.company" - trendige Mode für junge Leute. Selbstverständlich, allekostenlos.

"In addition, there are more than 20 specialized catalogs, such as „Multimedia“, „Baumarkt", „Klitzeklein“ „Gartencenter", ore "p.s. company”trendy fashion for young people. Of course, all for free."

(8) Otto existiertseit 1949. "Otto has existed since 1949."

(9) Im Herbst 1950 brachte unser Firmengründer, Werner Otto, den ersten Katalog heraus.

"In the fall of 1950, the first catalog brought our founder, Werner Otto, out."

(10)Dieser erschien in einer Auflage von 300 Exemplare, alle handgebunden, mit einem Angebot von 28 Paar Schuhen.

"This appeared in an edition of 300 copies, all hand tied, with an offer of 28 pairs of shoes."

(11) Erhatteübrigens 14 Seiten. "He had 14 pages, by the way."

(12) Und nach 50 Jahren ist die Otto-Handelsgruppe mit 51 Unternehmen in 20 Ländern in Europa, Amerika und Asien der einzige Global Player der Branche und das umsatzstärkste Versandunternehmer der Welt.
"And after 50 years, the Otto-trading group expanded into 51 companies in 20 countries in Europe, America and Asia the only global player in the industry and the most profitable shipping operators in the world."

(13) Der Konzern erwirtschaftet einen Jahresumsatz von 17 Mrd. Euro, etwa die Hälfte davon im Ausland.

"The group has an annual turnover of 17 billion Euros, about half of them abroad."

(14) Er beschäftigt 65000 Menschen. "He employs 65,000 people."

(15) Der Sitz der Handelsgruppe ist, wie gesagt, nach wie vor Hamburg.

"The headquarter of the trade group, as I said, is still Hamburg."

(16) In jüngster Zeit hat Otto seine Position in Großbritanien, dem zweitgrößten Versandhandelsmarkt Europas, entscheidend verstärkt.

"Recently, Otto has significantly strengthened its position in the UK, the second largest mail order market in Europe."

(17) Otto hat das britische Versandhandelsunternehmen Freemans Plc. London übernommen.

"Otto has taken over the British mail-order company, Freemans Plc. London."

(18) Dadurch hat Otto seinen Marktanteil an Versandhandel in Großbritanien von bisher 8 auf 15 Prozent erhöht.

"This has increased its market share of mail order in the UK from the current 8 to 15 percent."

(19) Der Otto Konzern plant, seine Marktposition in den großen Versandhandelsmärkten auszubauen. "The Otto Group is planning to expand its market position in the large mail order markets."

(20) Das war also ein kurzer Überblick über unsere Firma.

"That was a glimpse about our company."

(21) Möchte jemand eine Frage stellen?

"Would anyone like to ask a question?"

Besucher 1'visitor 1': (22) Entschuldigung, können sie den Umsatz bitte wiederholen? "Sorry, can you please repeat the sales?"

Sprecher "speaker": (23) Ja, wir haben einen Umsatz von 17 Mrd Euro weltweit "Yes, we have a turnover of 17 billion Euros worldwide."

(24) Hat jemandweitereFragen? 'Does anyone have any further questions?"

Besucher 2'visitor 2' (25) Ja, können Sie uns bitte etwas über Ihre Aktivitäten in Spanien sagen?"Yes, can you please tell us something about your activities in Spain?"

Sprecher 'speaker':(26) Ja, gerne.Wir verfolgen in 
Spanien ebenfalls einen Wachstumkurs.

'Yes, with pleasure. We also pursue in Spain a growth path'.

(27) Deshalb hat Otto beschlossen, ein Joint Venture mit dem Textileinzelhandels-unternehmen Inditex zu gründen.

"Therefore, Otto has decided to establish a joint venture with the textile retailer Inditex."

Besucher 2 'visitor 2': (28) Danke. "Thank you."

Sprecher 'speaker':(29) So, meine Damen und Herren, beginnen wir jetzt unsere Betriebsbesichtigung. "So, ladies and gentlemen, now we begin our factory tour."

In the data (1) GutenMorgen/Tag, meine Damen und Herren "Good morning ladies and gentlemen," it can be clearly seen that there are two types of speech acts, namely a) Gruß "greeting" and b) Anrede 'salutation' realized in the phrase of meine Damen und Herren "Ladies and gentlemen." The sentence of Zuerstmöchteich Ihnenkurzetwasüber den OttoKonzernerzählen "First, I would like to briefly tell you about the Otto Group" can be categorized into the speech act of the type of c) Ankündigung "information on what will be done by the speaker and interlocutor in the following minutes."

Sentences (4) to (19) are classified into the type of Mitteilungimengeren Sinne, such as the examples previously given. The sentence of Das war also einkurzer Überblicküberunsere Firma (20) "That was a glimpse about our company" is included as Redemittel to close a presentation. Then, the presenter opens the questionanswer session by asking the (21) sentence Möchtejemandeine Fragestellen? "Would anyone like to ask a question?" From its form, it can be readily known that the sentence is classified into the type of speech act of Frage "question"; more specifically, it is Entscheidungsfrage "a close-ended question." However, the question does not only expect a short answer, but also a further linguistic act, that the partner will ask a question in the given opportunity.

The question asked by guests or interlocutors to the presenter takes the form of Sachfrage, namely "openended question." The question is contained in the sentence (22) Entschuldigung, können Sie den Umsatz bitte wiederholen? "Sorry, can you please repeat the sales?" as well as the (25) sentence Ja, können Sieunsbitteetwasüber Ihre Aktivitäten in Spaniensagen? "Yes, can you please tell us something about your activities in Spain?" The guests as interlocutors ask for informative answers. After getting the answer, the interlocutors say thank you or Danke. The same is also true for the type of speech act of "thanking".

\section{CONCLUSION}

The data show that the type of speech acts, "notification in a narrow sense", dominates the text presentation of companies' profile. Almost all data provide information about the success of the company which ispresented along with the reasons of its success. Besides, there is information about activities or development programs implemented by the company. At the beginning of the presentation, there are "greeting" and "salutation" speech acts. At the end of the presentation, there is a "question" speech act in the form of "closed-ended" and "openended" questions. In addition, there is also "thanking" speech act, while "announcement" is the last type of speech act that provides notifications about things that will be done by the presenters and visitors in the visited company.

\section{REFERENCES}

Al-Shaer, I., M.R. (2013). Speech acts in American English and Palestinian Arabic. IJLLALW, 4(1), pp. 223-244. Retrieved May 7, 2015, retrieved from: www.ijllalw.org

Austin, J.L. 1962. How to do things with words. Oxford: Clarendon Press.

Bazerman, Ch. 2004. Speech acts, genres, and activity systems: How texts organize activity and people. University of California Santa Barbara. In Bazerman. Ch. \&Prior, P.2004. Mahwah, New Jersey, London: Lawrence Erlbaum Associates.

Brandt, P., Dietrich, R.A.,Schön, G. (2006). Sprachwissenschaft. 2. Auflage. Köln: Böhlau Verlag $\mathrm{GmbH} \&$ Cie.

Buhlmann, R.,Fearns, A.,Gaspardo, N. (2003). Präsentieren und verhandeln. Warschau: Poltext Verlag.

Debusmann, R. \&Kuhlmann, M. (2003). Dependency grammar: Classification and exploration. Saarland: Saarland University.

Engel, U. (1988). Deutsche grammatik. 2. Verbesserte auflage. Heidelberg: Julius Groos Verlag.

Gross, H. (1988). Einführung in die germanistische Linguistik. Heidelberg: Julius Groos Verlag.

Hutabarat, M. D.(1991). Analisis kontranstif pragmalinguistik gaya pernyataan terima kasih dan minta maaf antara Bahasa Jerman dan Bahasa Indonesia. Bandung: Fakultas Pendidikan Bahasa dan Seni- Institut Keguruan dan Ilmu Pendidikan.

Hutabarat, M. D. (2009). Analisis frasa verba tipe funktionsverbgefüge dan tipe fraseoleksemis dalam Bahasa Jerman Bidang Ekonomi. Unpublished Dissertation. Universitas Padjadjaran Bandung.

Hutabarat, M. D.(2013). Einführung zu sprechübungen.Allemania. Jurnal Bahasa dan Sastra Jerman, 2(2), pp. 89-99.

Karagjosova, E. (2007). Satztypen und Sprechakte. Frankfurt am Main: Universität Oslo.

Lewandowski, T. (1990). Linguistisches Wörterbuch. Band 3. 5. Überarbeitete auflage. Heidelberg Wiesbaden: Quelle \& Meyer Verlag.

Meibauer, J. (2007). Einführung in die germanistische 
Hutabarat, Speech acts on company's presentation in German for...

Linguistik. 2. Auflage. Stuttgart: Metzler Verlag. Oishi, E. (2006). Austin's speech act theory and the speech situation. EserciziFilosofici, 1, pp. 1-14, Retrieved from: http://www.univ.trieste.it/ eserfilo/art106/oishi10 6.pdf

Subyakto, S. U. (1990). Pragmalinguistik kontranstifSuatu penjajakan gaya komunikasi antara Bahasa
Inggris dan Bahasa Indonesia. IKIP Jakarta. Penelitian Hibah dari DIKTI.

Tarvainen, K.(1981). Einführung in die

Dependezgrammatik. Tübingen: Max Niemeyer Verlag.

Tesnière, L. (1959). Éléments de syntaxestructurale. Paris: Klincksieck. 